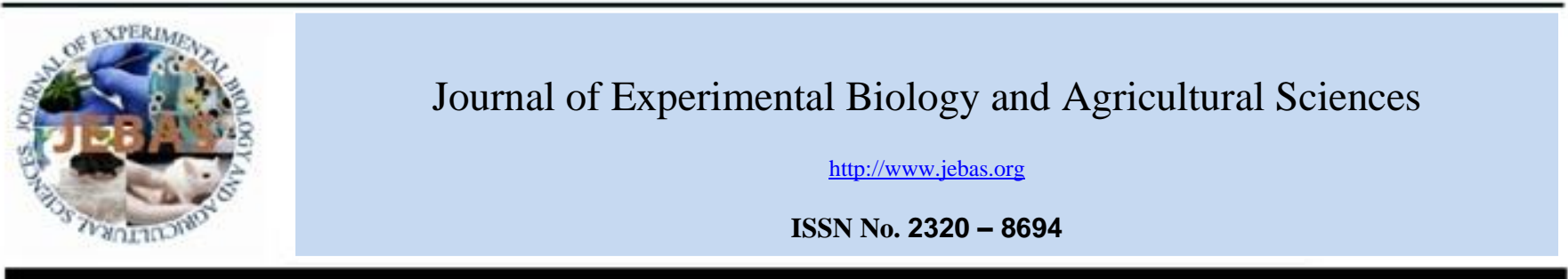

\title{
IMPACT OF IMPROVED TECHNOLOGY FOR ENHANCING WHEAT PRODUCTIVITY IN WEST BENGAL
}

\section{Dhiman Mukherjee}

Directorate of Research, Bidhan Chandra KrishiViswavidyalaya, Kalyani-741235, West Bengal, India

Received - August 21, 2017; Revision - January 19, 2018; Accepted - February 13, 2018

Available Online - February 20, 2018

DOI: http://dx.doi.org/10.18006/2018.6(1).258.263

\section{KEYWORDS}

FLD

Improved cultivar

Socio-economic constraints

Wheat

Yield

\begin{abstract}
Field trials were conducted in farmers' fields of Nadia and Murshidabad district of West Bengal, India under frontline demonstration to study the potential of new technology with new genotype. Present FLD programme was conducted with the objective to increase wheat production capacity and enhance farmer income per unit area. Demonstration programme was conducted during rabi season of 2016-17 along with 162 unit with improved wheat culver viz. HD2967. Improved cultivation practices in newly introduced cultivar gave $39.75 \mathrm{q} /$ ha grain yield and showed better performance to over age old cultivar UP 262 and Sonalika. Further, HD 2967 gave 56.91\% higher grain yield than the Sonalika (local check). Stover production was high with HD 2967 (57.79 q/ha) compared to local check variety (39.98 q/ha). Improved variety registered $30.81 \%$ more straw yield over the traditional variety of farmers. Economics revealed that FLD plot registered more gross return (Rs. 82,316/ha) and higher B:C ratio (1.80).
\end{abstract}

* Corresponding author

E-mail: dhiman_mukherjee@yahoo.co.in (Dhiman Mukherjee)

Peer review under responsibility of Journal of Experimental Biology and Agricultural Sciences.

Production and Hosting by Horizon Publisher India [HPI] (http://www.horizonpublisherindia.in/).

All rights reserved.
All the article published by Journal of Experimental Biology and Agricultural Sciences is licensed under a Creative Commons Attribution-NonCommercial 4.0 International License Based on a work at www.jebas.org.

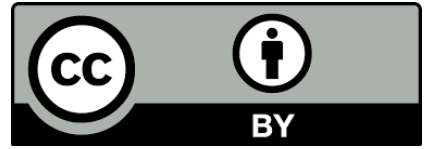




\section{Introduction}

Wheat is the second most important winter cereal in India after rice contributing substantially to the national food security by providing more than $50 \%$ of the calories to the people who mainly depend on it. In historical perspective India had made spectacular advancement in productivity and sustainability of wheat and wheat based cropping system. The scenario of the past ten years has clearly indicated that the wheat production in the country has soared ahead despite area remaining the same. According to Joshi et al. (2014) this is mainly because of poor technological intervention in north eastern plain zone (NEPZ). Recently due to change in food habit particularly in West Bengal and Southern State of India, this crop becomes favorite to the growers. North Eastern Plain Zone is not a traditional wheat growing area in India, however different state under this zone become prime focus for another green revolution (Mukherjee, 2016). Exploiting this area for wheat production has become a challenging task especially for West Bengal. In spite of a wide range of adoptability, little attention has been paid towards wheat production and maximization of yield potential of this crop mainly in few states (West Bengal, Bihar, Jharkhand etc.), and its share to national production is less than $1 \%$ (Anonymous, 2016). Productivity of these states confined to $2.8 \mathrm{t} \mathrm{ha}^{-1}$, and is far below the national average of $3.14 \mathrm{t} \mathrm{ha}^{-1}$ (Mukherjee, 2017). Amongst the various productions technology of wheat, suitable genotype and good agronomic practices plays a significant role for optimum output in term of yield. Usually farmers were unaware about the suitable cultivar due to poor extension support system (Sharma \& Choudhary, 2014). Front Line Demonstration is one of the most powerful tools for transfer of technology, and this may be very helpful for new alluvial zone farmers. The main objective of front line demonstrations is to demonstrate newly released crop production and protection technologies and its management practices in the farmers' field. The scientist are required to study the factors contributing higher crop production, field constraints of production and thereby generate production data and feedback information. Keeping in view of an effective extension approach of FLDs for dissemination of wheat technology, it was thought that impact of FLDs conducting by our unit was to be assessed. Various observation during our study programme revealed that, most of the wheat growers stick to the age old traditional variety, which gave very poor return to the farmers. Hence, an effort made by scientist of AICPR on Wheat and Barley improvement, BCKV, Kalyani by introducing new wheat cultivar with improved technologies for enhancing wheat production through frontline demonstration.

\section{Materials and Methods}

Present work was conducted during rabi season of 2016-17 in two different district of Nadia and Murshidabad of West Bengal, as mandatory programme of All India Coordinated Research Programme on Wheat and Barley Improvement, under the aegis of Bidhan Chandra KrishiViswavidayalaya, Kalyani, West Bengal, India. Under this programme, extensive training and field day was conducted to excel wheat grower's better know how and skill about the recent technology of cultivation. All the demonstration work was conducted under strict supervision of scientist and technical staff of the AICRP unit. Sixteen number of demonstration was conducted (eight in each district) with the objective to enhance wheat grower income and change in cropping pattern from rice -rice to rice -wheat system. Under demonstration plot, improved cultivars with need based agronomic management were adopted. Trial mainly comprised of newly introduced high yield variety i.e. HD 2967. Farmer's practice mainly includes UP 262 and Sonalika wheat cultivar (Table 1). Sowing time of crop was same in demonstration plot and famer field. All other steps like site choice, farmer's selection, design of demonstration, farmers involvement etc. were charted as suggested by Choudhary (1999). For clarification of outcome, $8 \times 8 \mathrm{~m}^{2}$ plot harvested in three different locations in each demonstration and farmer's practice plot. Grain weight measured in term of quintal per hectare $(\mathrm{q} / \mathrm{ha})$. To know the economics cost of cultivation, net returns and benefit cost ratio (B:C ratio) were calculated by using prevalent prices of inputs and outputs.

\section{Result and discussion}

Present FLD programme was conducted in ten hectare area and farmers who generally use the old varieties and don't follow proper irrigation schedule and don't apply the recommended dose of fertilizers were selected. Split application of recommended dose of nitrogen i.e. $75 \mathrm{~kg}$ per hectare (half of the recommended dose) in the form of urea, full dose of phosphate (60 kg / ha) and potash (40 kg/ha) in the form of SSP and MOP, respectively were applied uniformly as basal dose. Remaining part of nitrogen i.e. $75 \mathrm{~kg} /$ ha (half dose) in the form of urea was top-dressed at first irrigation i.e. 21 days after sowing. The crop was irrigated four times ( first one at CRI stage, second one at jointing, third at flowering and fourth at soft dough stage of the crop) based on soil moister content. The farmers usually adopt broadcasting of seed, however in present study, an attempt to convince them about line sowing was carried out, but studied respondents denied to follow the given suggestion due to labour problem (Meena et al., 2016).Usual farmer exercise vary from demonstrated plot in term of date of sowing, fertilizer application and number of irrigation and few other agronomic practices i.e. weed control etc. (Table 1). Enhanced skill involvement with suitable variety, revealed that 
Table 1 Components of the FLD and farmer's practices

\begin{tabular}{|c|c|c|c|}
\hline S. No. & Particulars & FLD plot & Farmer's practice \\
\hline 1. & Date of sowing & 17.11.16 to 24.11 .16 & 20.11 .16 to 25.11 .16 \\
\hline 2. & Variety & HD 2967 & UP 262 and Sonalika \\
\hline 3. & Seed Rate used (kg/ha) & $100(\mathrm{~kg} / \mathrm{ha})$ & 125 (kg/ha) \\
\hline 4. & Duration of the variety (in days) & 114-118 (HD2967 ) & 114-118 days \\
\hline 5. & Name of previous crop & Rice & Rice/pulse \\
\hline 6. & Type of soil & Clay loam, Loam & Clay loam, Loam \\
\hline 7. & Fertility status (Low / Medium / High) & Medium & Medium \\
\hline 8. & Fertilizer used (N:P:K in kg/ha) & $\begin{array}{l}\mathrm{N}: 150 \quad \text { P: } 60 \quad \mathrm{~K}: 40 \\
\text { (based on soil test value) }\end{array}$ & 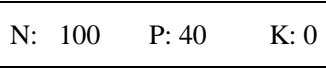 \\
\hline 9. & Sowing methods & $\begin{array}{l}\text { Line sowing } \\
(20 \mathrm{~cm} \text { row to row spacing })\end{array}$ & Broadcasting \\
\hline 10. & $\begin{array}{l}\text { Irrigation type (Tube well/Canal/Well/Tank } \\
\text { irrigated) }\end{array}$ & Tube well & Tube well \\
\hline 11. & Number of irrigations & Four to five & Three \\
\hline 12. & Time of harvesting & 24.03 .17 to 04.04 .17 & 02.04 .17 to 12.04 .17 \\
\hline 13. & $\begin{array}{l}\text { Harvesting method used (Combine / } \\
\text { Manual) }\end{array}$ & Manual & Manual \\
\hline 14. & $\begin{array}{l}\text { Threshing method } \\
\text { (Thresher/Bullock/Manual/Other) }\end{array}$ & Manual & Manual \\
\hline 15. & Price of grain (Rs./quintal) & Rs. 1935 /q & Rs. $1860 / \mathrm{q}$ \\
\hline 16. & Price of straw (Rs./quintal) & Rs. $93.50 / \mathrm{q}$ & Rs. $93.50 / \mathrm{q}$ \\
\hline
\end{tabular}

Table 2 Cultivar, area, economic and straw yield under FLDs and farmer's practice

\begin{tabular}{|c|c|c|c|c|c|c|c|}
\hline \multicolumn{4}{|c|}{ FLD plot } & \multicolumn{4}{|c|}{ Farmer's practice } \\
\hline $\begin{array}{l}\text { Name of } \\
\text { cultivars }\end{array}$ & $\begin{array}{c}\text { Area } \\
\text { sown (ha) }\end{array}$ & $\begin{array}{l}\text { Grain } \\
\text { yield (q/ha) }\end{array}$ & $\begin{array}{c}\text { Stover } \\
\text { yield (q/ha) }\end{array}$ & $\begin{array}{l}\text { Name of } \\
\text { cultivars }\end{array}$ & $\begin{array}{c}\text { Area } \\
\text { sown (ha) }\end{array}$ & $\begin{array}{c}\text { Grain } \\
\text { yield (q/ha) }\end{array}$ & $\begin{array}{c}\text { Stover } \\
\text { yield (q/ha) }\end{array}$ \\
\hline *HD 2967 & 4.25 & 40.56 & 57.38 & UP 262 & 0.91 & 26.55 & 39.46 \\
\hline \multirow{2}{*}{ **HD 2967} & \multirow{2}{*}{5.75} & \multirow{2}{*}{38.94} & \multirow{2}{*}{58.20} & UP 262 & 0.79 & 23.20 & 37.25 \\
\hline & & & & Sonalika & 0.46 & 26.26 & 43.23 \\
\hline Total/Mean & 10.00 & 39.75 & 57.79 & & 2.16 & 25.33 & 39.98 \\
\hline
\end{tabular}

* Murshidabad District (Golahat and Jalangi block), ** Nadia District (Kanchrapara and Kalyani block)

economic (grain) yield of HD 2967 (39.75 q/ha) was quit good enough compared to traditional variety of UP 262 and Sonalika $(25.33 \mathrm{q} / \mathrm{ha})$. Use of good cultivar resulted $56.91 \%$ grain yield which is significantly superior to the grain yield of UP 262 and Sonalika (Table 2). Stover yield was quite prominent in case of HD 2967 (57.79 q/ha) and showed better performance over the farmer cultivars (39.98 q/ha) (Table 2). Further, improved variety registered $30.81 \%$ more straw yield over the traditional variety of farmers. Benefit: cost ratio exposed that farmer outflow towards the husbandry of wheat was Rs. 35,100/ha compared to new variety in demonstration plot of Rs. 45,600/ha. This high cost was chiefly due to better variety, cost of inputs, irrigation and other post-harvest management (Table 3). Higher B : C ratio observed with FLD plot (1.80) and was very much acceptable by the local growers. Similar kind of observation reported by Meena et al (2016).With the above outcome, FLD were carried out in proper 
Table 3 Assessment of different technology intervention on economics of wheat

\begin{tabular}{|c|c|c|}
\hline Operations & FLD plot & Farmer's practice \\
\hline 1. Land preparation & 5000 & 5000 \\
\hline 2. Sowing cost (including seed cost) & 5400 & 4800 \\
\hline 3. Composts cost & 1200 & 1200 \\
\hline 4. NPK cost & 3850 & 2050 \\
\hline \multicolumn{3}{|l|}{ 5. Plant protection chemicals } \\
\hline a. Herbicides & 1400 & 600 \\
\hline b. Chemical insecticides & 200 & \\
\hline c. Fungicide & 200 & 400 \\
\hline 6. Irrigation & 1600 & 1400 \\
\hline 7. Manual weeding & 2500 & 1000 \\
\hline \multicolumn{3}{|l|}{ 8. Harvesting } \\
\hline a. Manual harvesting & 7550 & 7550 \\
\hline \multicolumn{3}{|l|}{ b. Combine harvester } \\
\hline 9. Watch \& ward & 5000 & 5000 \\
\hline 10. Threshing \& winnowing & 5700 & 4700 \\
\hline 11. Drying, Weighing, Bagging & 6000 & 1400 \\
\hline Total expenditure (Cost of cultivation & 45600 & 35100 \\
\hline Gross return & 82319 & 47113 \\
\hline $\mathrm{B}: \mathrm{C}$ ratio. & 1.80 & 1.34 \\
\hline
\end{tabular}

and scientific manner on farmer's field to show the value of a new change, and convincing agricultural community about potentialities of better invention technologies of wheat for further adoption (Joshi et al.,2014 ). Response receives from different farmer's revealed that farmer were very much benefitted with the FLD and their response were quite good and positive. This corroborate with the earlier work of Mishra et al. (2009). The farmers became familiar with novel cultivars of wheat and came to recognize more about improved wheat production through these programmes. Farmers from FLDs field trials, were happy because better varieties did better yield and fetch more economic returns than the check cultivar. Agro-ecological restraints exposed that few of stern disease and weeds were observed. Adjacent farmers' reaction was positive about the demonstrated FLD. With the above study, we came to conclusion that, wheat FLDs were perceived by the farmers as effective method of transfer of technology from field to knowledge level of farmer's. No serious diseases, neither in demonstration plot nor in check plot except few cases in Jalangi, Murshidabad district were reported during FLD programme. Few notable, observation on termite infestation were reported in few pockets. Further findings of present study revealed that, usually famer lack the knowledge of suitable dose and technique of herbicide use. Aggravated problem of Cyprus rotundus,Chenopodium album, wild rice and Rumexdentatus observed (Table 4). Under abiotic stress, water shortage and high temperature at maturity was also become severe restraints. With discussion to the farming community, it came to know that lack of information among farmers about recent knowledge and poor contribution of farmer in exposure visits was most restraining factor for enhancing wheat production. Day to day observation of present study revealed that, poor land holding and lack of suitable mechanized technology was one of the most important constraints. 
Table 4 Agro - economical, technical constraints /problems limiting wheat yields in the area

S. No. Constraint/Problem

MS S NS S.No. Constraint/Problem

V. Socio-economic

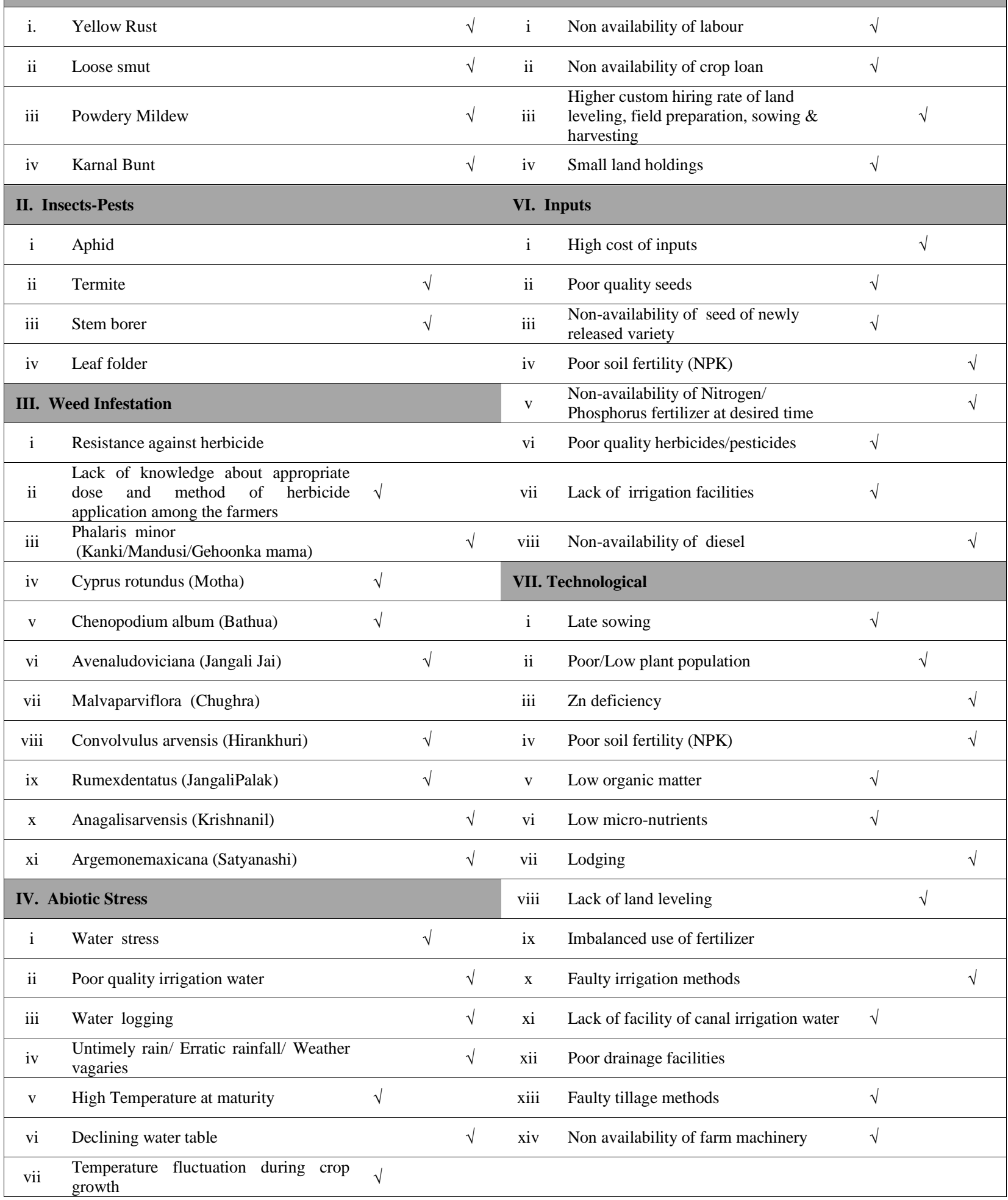

Journal of Experimental Biology and Agriculture Science

http://www.jebas.org 


\begin{tabular}{|c|c|c|c|c|c|c|c|c|c|}
\hline S. No. & Constraint/Problem & MS & $\mathbf{S}$ & NS & S.No. & Constraint/Problem & MS & $\mathbf{S}$ & NS \\
\hline \multicolumn{4}{|c|}{ VIII. Extension } & & \multicolumn{5}{|c|}{ IX. Others } \\
\hline $\mathrm{i}$ & $\begin{array}{l}\text { Lack of knowledge among farmers } \\
\text { about recent technologies }\end{array}$ & $\sqrt{ }$ & & & $\mathrm{i}$ & Non-availability of electricity & & & $\sqrt{ }$ \\
\hline ii & $\begin{array}{l}\text { Poor information delivery by state } \\
\text { extension machinery }\end{array}$ & $\sqrt{ }$ & & & ii & Erratic power supply & & & $\sqrt{ }$ \\
\hline iii & $\begin{array}{l}\text { Poor participation in exposure visits } \\
\text { arranged by various departments }\end{array}$ & & $\sqrt{ }$ & & iii & Low price of wheat / barley & & $\sqrt{ }$ & \\
\hline iv & $\begin{array}{l}\text { Poor participation in kisanmelas/ } \\
\text { field day/kisangoshthi/ training }\end{array}$ & & $\sqrt{ }$ & & iv & Problem in marketing of wheat / barley & $\sqrt{ }$ & & \\
\hline $\mathrm{v}$ & Lack of extension literature & $\sqrt{ }$ & & & $\mathrm{v}$ & Birds & $\sqrt{ }$ & & \\
\hline vi & Lack of training facility & $\sqrt{ }$ & & & vi & Rodents & & $\sqrt{ }$ & \\
\hline
\end{tabular}

MS: Most Serious S: Serious (S): NS : Not Serious (NS)

\section{Conclusion}

Study revealed that, frontline demonstration convincingly brought out that the yield of wheat could increased higher with the intervention on varietal replacement and improved technology viz. appropriate nutrient and weed management and proper irrigation in wheat. To safe guard and sustain the food security in India, it is quite important to increase the productivity of wheat under limited resources. Favorable benefit cost ratio is self-explanatory of economic viability of the demonstration and convinced the farmers for adoption of improved technology of wheat production. The technology suitable for enhancing the productivity of wheat and calls for conduct of such demonstration under the transfer of technology programme by various extension functionaries.

\section{Acknowledgement}

Author is highly thankful for the fund support received from Indian Institute of wheat and barley research, Karnal, Haryana for this FLD programme and supply of seed materials. Further, thankful to technical staff of All India Wheat and Barley project for their sincere effort for data recording and critical observation. Lastly, the support received from the farmer of Majherchar and Jalangi block is highly acknowledgeable.

\section{Conflict of Interest}

The author hereby declared no potential conflicts of interest with respect to the research or publication of this article.

\section{References}

Anonymous (2016) Progress report of All India Coordinated
Wheat and Barley Improvement Project 2015-16.Director's report. InSingh GP (Ed.), ICAR-Indian Institute of Wheat and Barley Research, Karnal, India, Pp. 96.

Choudhary BN(1999) Krishi vigyan Kendra- A guide for KVK mangers. Publication, Division of Agricultural Extension, ICAR, Pp73-78.

Joshi NS, Bariya MK, Kunjadia BB (2014) Yield gap analysis through front line demonstration in wheat crop. International Journal of Scientific and Research Publications 4 : 64-75.

Meena KC, Lakhawat S, Gupta IN (2016) Performance of wheat variety through FLDs in Hadauti region of Rajasthan. International Journal of Science, Environment and Technology, 5:1758-1764

Mishra DK, Paliwal DK, Tailor RS, Deshwal AK (2009) Impact of frontline demonstrations on yield enhancement of potato. Indian Research Journal of Extension Education $9: 26-28$.

Mukherjee D (2016) Evaluation of different crop sequence productivity potential, economics and nutrient balance under new alluvial situation of NEPZ. International Journal of Horticulture and Agriculture1: 5 .

Mukherjee D (2017) Evaluation of performance of new wheat cultivar under different row spacing. International Journal of Current Microbiology and Applied Sciences 6:165-178.

Sharma R, Choudhary PC (2014).Improvement in wheat productivity through frontline demonstrations. Indian Journal of Extension Education 22:36-41. 